\title{
Making climate change visible: A critical role for landscape professionals Dr. Stephen Sheppard, UBC
}

Author's prepublication copy 


\section{Landscape and Urban Planning - Perspective Essay (revised) - 3 July 2015}

\section{Introduction}

Climate change is getting worse, but society is not responding accordingly (IPCC, 2014). Scientists have become very worried and are increasingly trying to communicate better, some of them (such as James Hansen, formerly Director of NASA's Goddard Institute for Space Studies) even becoming activists (Mann, 2014). However, psychological research and the evidence of global politics confirm that science and science communication are not enough to stimulate behaviour change or substantive action on the climate crisis (Moser and Dilling, 2007). This essay discusses the need for experiential learning, place attachment, social pressure at the local level, as well as enhanced planning, to help mobilize community-level awareness and action on climate change. It explores the unique potential of local landscapes, landscape professionals, and their visual media in helping to deliver or reinforce these as catalysts of social change, through making climate change more visible where people live.

This essay draws on concepts and examples advanced in the author's book on Visualizing Climate Change (Sheppard, 2012), in order to convey some of its key messages to a wider readership, and particularly to encourage further discussion and development of a leadership role for landscape professionals in addressing climate change. Intended for a general audience, the book proposes a new way of seeing our communities: through a perceptual climate change lens which can reveal what climate change looks like in everyday landscapes, and help develop the public's literacy on climate change at the neighbourhood scale (Sheppard, 2012). This calls for landscape-based approaches and landscape architectural tools, to help people read the signs of climate change all around them, engage in responding to climate change, and foresee future consequences of their action (or inaction). The book argues that the local landscape scale and these techniques have been largely neglected by scientists and most policy makers working on climate change.

Accordingly, this essay both summarizes and goes beyond the author's previous work, in advocating a key role and an urgent moral imperative for landscape professionals to become more prominent actors in social change on climate change issues. By applying our special skills in revelatory design, landscape visualization, and visioning methods, perhaps we can help communities to see and engage with climate change better at the local level. Building on broad principles and two frameworks outlined in Visualizing Climate Change, this essay focuses on roles and specific pathways through which landscape professionals (defined here as landscape architects and planners, landscape researchers, and related communications practitioners) can contribute to community capacity-building and better climate change planning processes. The essay also reflects further development of several concepts and findings since Visualizing Climate Change was published.

The rest of this essay proceeds with general principles from the literature on better engagement of the public on climate change (Section 2); the unique potential of landscape in engaging people with climate change, leading to a framework for integrating landscape with behaviour change and climate action (Section 3); the need to consider all aspects of climate change holistically in learning to recognize it in the landscape, introducing a second framework for categorizing climate change features in communities (Section 4); development of critical roles, 
guidelines, and pathways for landscape professionals to engage in this area of work (Section 5); and concluding recommendations.

\section{Problems and principles in engaging society on climate change}

Even in America, where climate change is still denied by some, a majority of the public has long had a concern over climate change (Leiserowitz et al., 2009; Nordhaus \& Shellenberger, 2009). Yet, despite this and the scientific consensus, society at large has been slow to act. According to psychologists, there are many social barriers to action on climate change (Gifford, 2011), due in part to perceptual gaps that exist in connecting climate change to people. Science and science communication are usually not enough to change minds, behaviour, or policies, and are often abstract and remote for lay-people (Moser \& Dilling, 2007). Professional experience and research (e.g. O'Shea, 2014) suggest that conventional outreach, planning processes, and policies are also not reaching or mobilizing communities substantively. For example, despite British Columbia's aggressive province-wide emission reduction targets $(80 \%$ reduction by 2050 from 2007 levels), a recent survey found that most respondents were not aware of any of British Columbia's climate policies (Rhodes et al., 2014).

One of the perceptual disconnects is the relative invisibility of climate change and greenhouse gases (GHGs) (Metz \& Below, 2009; Moser \& Dilling, 2007). Even though scientists warn of doom \& gloom, and extreme weather events periodically dominate the news, most of the time (especially in developed countries) it is hard to believe the truth about climate change, as it is difficult to see. As McKibben (2012) puts it: " it is hard to picture climate change, because carbon dioxide is invisible - if it were brown, we would have stopped producing it long ago." Because "our daily perceptions appear to contradict the serious messages issuing from the IPCC" (Castree, 2015), we find it difficult to connect the dots across scales and distances in space and time, such as between:

- "everyday community environments and global climate change, local landscapes to climate change science, or urban lifestyles to changes on the land beyond the city

- the causes of climate change and the resulting impacts, linking local causes and distant effects, or current habits with future conditions" (Sheppard, 2012, p27).

The future is of course not visible and therefore gets discounted, not just by economists (Pahl et al., 2014).

The social and psychological literature on climate change suggests that we need more than information alone to bridge these perceptual gaps and reach the public. Van Der Linden (2014) argues that public campaigns need to make the climate change context explicit, and argues for integrating the knowledge/information approach with the 'affective-experiential' and 'socialnormative' approaches, in order to influence behaviour. Recommendations often invoke the following specific approaches:

- Experiential learning (Weber, 2006), involving personal experience with emotional meaning in order to engage people in active social environments

- Place attachment, caring about your 'hood' due to individually or collectively determined meanings, related to spatial characteristics and the prominence of specific social or physical elements in the landscape (Scannell \& Gifford, 2010).

- Social or peer pressure, motivating behaviour through comparison with others. Our neighbours can be a powerful force, encouraging uptake of climate change solutions or representing a critical barrier to behaviour change. The "eyes on the street" effect means that practical actions taken by neighbours to fight climate change can be immediately seen 
and shared, helping to establish new social norms from observation of what is considered the appropriate course of action (APA, 2009).

- Use of visual learning tools to make climate change attributes more "concrete" to people (Leiserowitz, 2007) and act as prompts for behaviours (McKenzie Mohr \& Smith, 1999). Visual media and realistic experiential landscape visualization in particular have been found to increase engagement, enhance learning, tap emotions, and affect behaviour in some cases (e.g. Bishop et al., 2001; Schroth, 2010; Sheppard, 2005; Winn, 1997).

These findings can be distilled into three broad principles for engaging the public on climate change more meaningfully (Sheppard, 2012):

- Make it local: making climate change more salient and immediate by pulling it into a community context that people care about, using the local landscape to express climate change issues and focus action;

- Make it visual: harnessing the power of visual perception and imagery in making concepts and realities of climate change and carbon both clear and compelling; showing what climate change really looks like;

- Make it connected: looking holistically at the 'big picture' on climate change, integrating all aspects of climate change that interact with society and affected environments across scales - e.g. "relating local conditions to remote impacts, and linking current trends to future conditions" (Sheppard, 2012, p61).

\section{The special role of landscape in engaging society on climate change}

The role and scale of landscape as a social mobilization device appears to have been largely neglected in the mainstream climate change discourse. The science and policy dialogue has usually focused on global or national levels, while popular interpretation of the science and even practical government attempts to change behaviour (e.g. on energy efficiency) tend to focus on the individual person or household. Where the local scale has been considered by planners and social scientists, it often focuses on the policy role of local government, and less on place-based aspects of community and neighbourhoods to which citizens can more easily relate. Increasingly, we have seen community scale planning efforts such as Community Energy and Emission Plans and city adaptation plans (e.g. ICLEI, n.d), but the role of landscape as both experiential medium and visual message is often missing from consideration. Many do not even address mapping (e.g. Snover et al., 2007).

Yet, landscapes appear to offer the kind of integrative frame or context that Van Der Linden (2014) advocates for climate change engagement. They are by their nature local, visual, and holistic. They combine what Nassauer (2012) has termed 'the experiential and analytical': "Landscape is a visible and noticeable artifact of often unnoticed and sometimes invisible natural and societal processes. Because landscapes are visible, landscape can bring different people into a common experience of environmental systems...... This landscape scale links everyday experience with other environmental phenomena that are not directly perceived", (Nassauer, 2012, p222). Through analysis of and interventions in this 'perceptible realm' (Gobster et al., 2007), the local and visible aspects of climate change may be highlighted to make climate change real and meaningful for people where they live, as in photographs of climate-related conditions (Figure 1). A more tangible, immediate, and recurring image of climate change that is 'in your face' may help break down what Marshall (2014) calls 'the silence of climate change', whereby it remains off the table for serious ongoing discussion 
among affected parties (i.e. all of us).

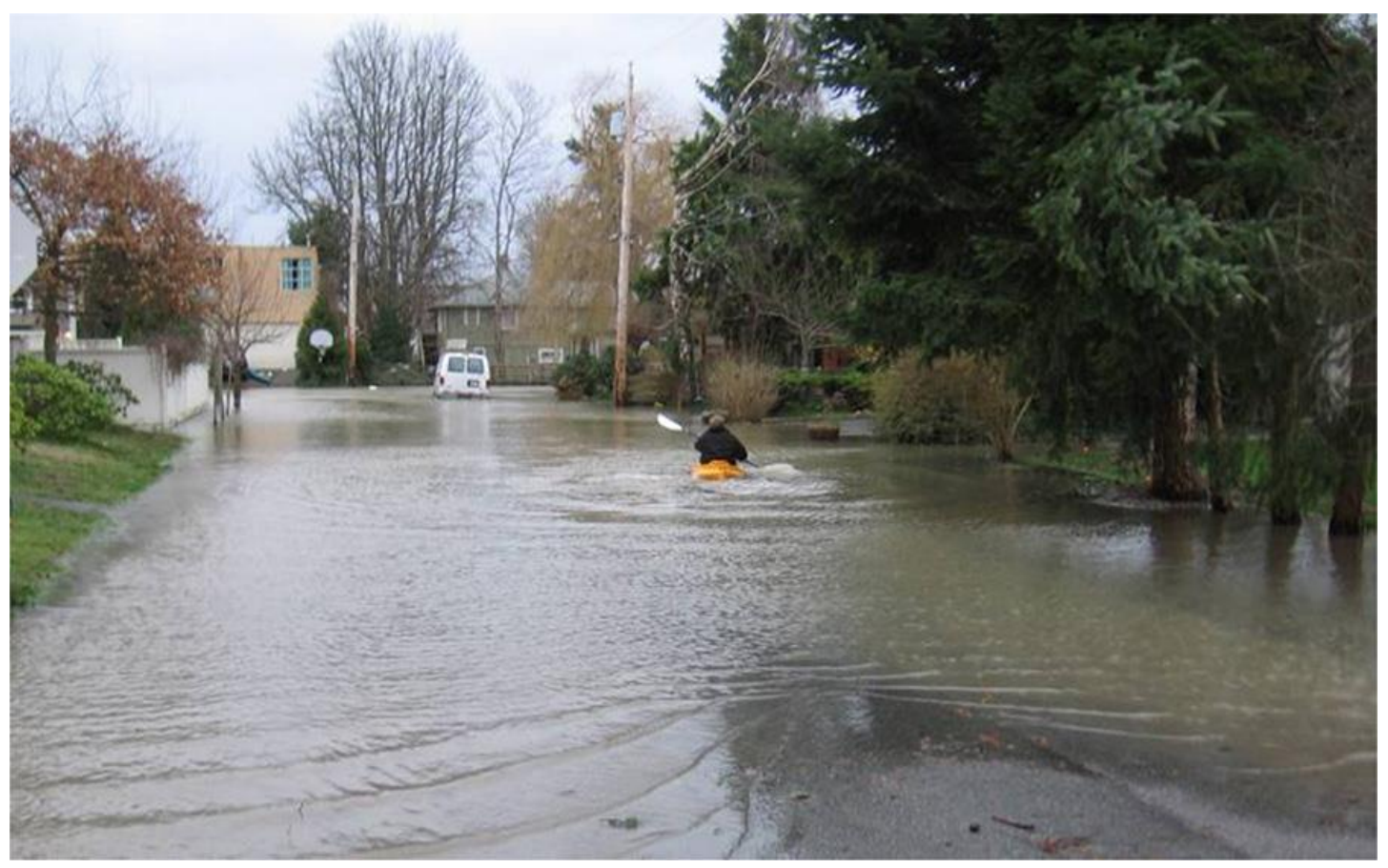

Figure 1. Residents of this flood-prone area of south Delta, BC, experience coastal flooding and are from time to time visibly reminded of their vulnerability to climate change.

Photo: H. Fraser, Corporation of Delta. Reproduced from 'Visualizing Climate Change' (Sheppard, 2012) with permission from Taylor and Francis.

For many in developed countries, the dominant stream of information on climate change has come from scientists and their opposition -- the so-called 'two sides of the debate', but mostly filtered by the media (Boykoff, 2011). "Perhaps the most important rationale for a landscapebased perspective is to provide a third way for people to know about climate change" (Sheppard, 2012, p44). Local landscapes provide an alternative channel, the evidence of our own eyes, which offers a third and largely independent way to learn about climate change (ie. first hand), in the here and now. It can triangulate the science, making it easier for communities to make sense of scientific information by contextualizing it in real places.

This essay argues that seeing evidence of climate change locally matters a lot, through reinforcing with visible evidence what people already know about climate change. In Sheppard (2012), the author describes a new Community Awareness to Action (C2A) Framework, which adds the experience of seeing climate change to earlier simpler models of factors contributing to action on climate change solutions (Figure 2). External influences shown here include both conventional climate change information (mainly via mass media) and direct experience in the local landscape. Without visible, locally seen evidence of climate change, we may hear and even know about climate change from other sources, but are rarely moved to action in the face of prevailing social norms (such as commuting by car to work, heating homes with natural gas, watering lawns, etc.). However, the $\mathrm{C} 2 \mathrm{~A}$ framework theorizes that when the local environment directly contributes robust visible evidence of climate change to people, the combination of knowing and seeing (Carlson, 2001) leads to recognition: "consciously noticing (signs of climate change) in our environment and understanding their significance" (Sheppard, 
2012, p81). This insight at the local level may in turn stimulate caring more effectively than conventional information on its own, due to personal and place-based connections which may increase motivation to do something about climate change.

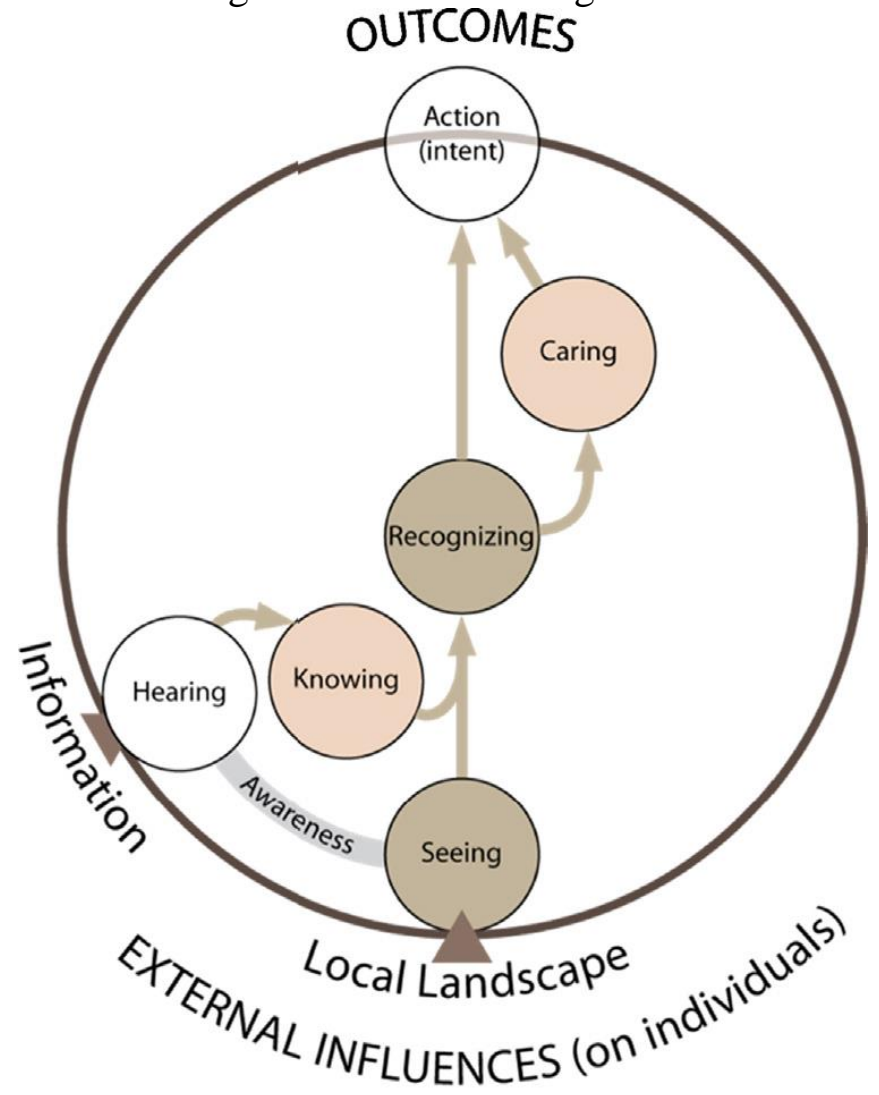

Key Influences

Figure 2. The Community Awareness to Action (C2A) Framework, represented as a simple flow-diagram incorporating both knowing and seeing as potential contributors to action on climate change.

Graphic: J. Myers. Reproduced from 'Visualizing Climate Change' (Sheppard, 2012) with permission from Taylor and Francis.

Figure 3 provides a more complete and nuanced version of the simple relationships theorized in the $\mathrm{C} 2 \mathrm{~A}$ framework diagram (Figure 2). The current reality is that reliance on media for information about climate change, the weakness of current planning and policy mechanisms in reaching the public, and the stilted conversations about climate change in society, amount to weak drivers of caring and action. Figure 3 represents the much stronger role that the landscape could play in enabling fuller recognition of climate change messages among citizens, bringing home the reality of climate change in a way that relates to the individual's sense of identity, security, and responsibility. This improved climate literacy may in turn result in people caring and acting more, especially if reinforced by the following trends (also shown in Figure 3):

- a shift in attitudes of local cultural groups in recognizing climate change realities and needed responses in the community, at the collective level of cultural cognition (Kahan, 2010),

- improved ways of making relevant climate change science resonate with the public,

- more effective and inclusive community planning processes addressing future solutions. 


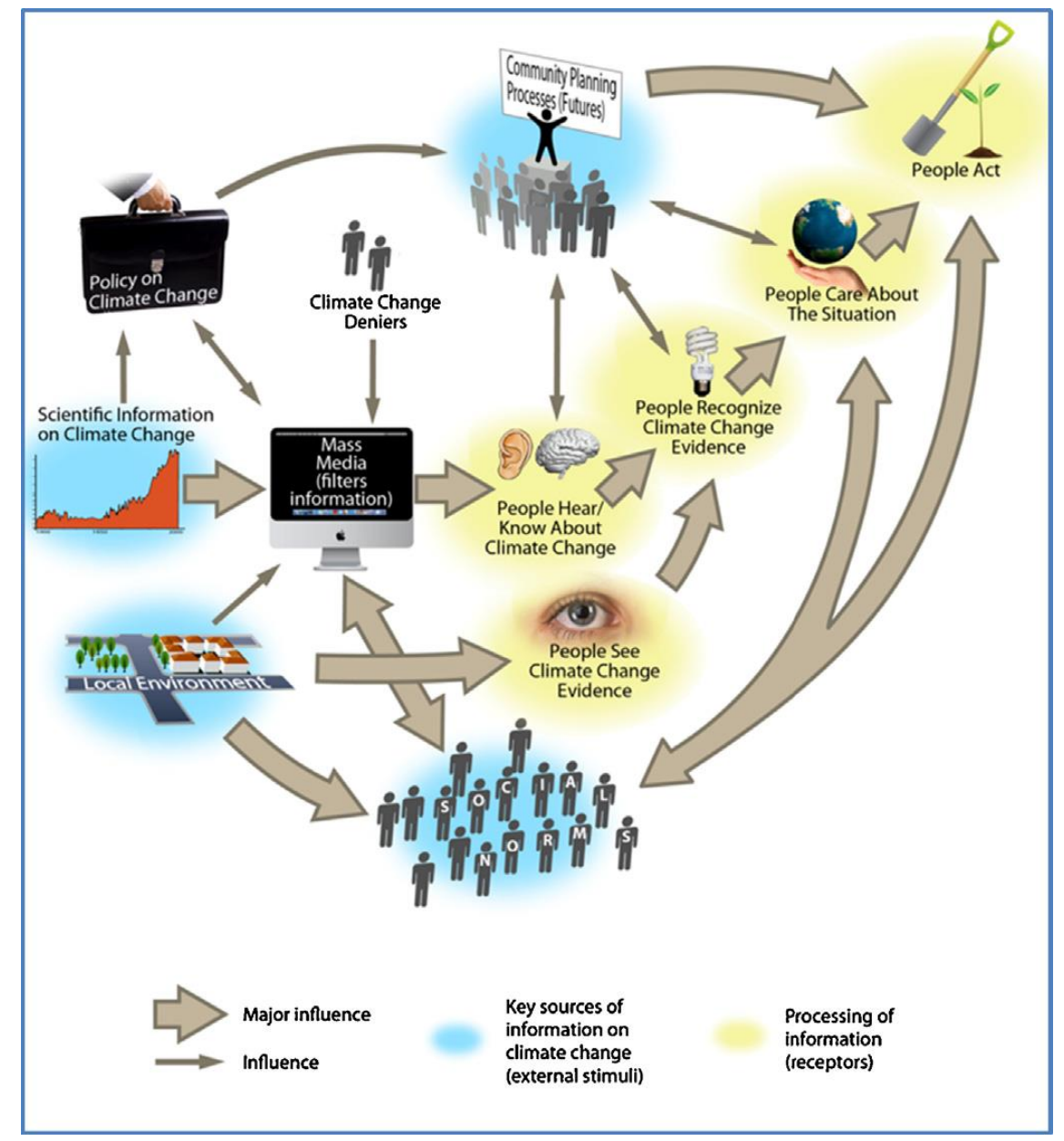

Figure 3. A more detailed version of the Community Awareness to Action Framework, reflecting more factors and showing potentially enhanced sources of climate change information (including strong signals from local landscapes) and their influence on peoples' responses.

Graphic: J. Myers. Reproduced from 'Visualizing Climate Change' (Sheppard, 2012) with permission from

Taylor and Francis.

Evidence is accumulating that people are now starting to recognize climate change. Two months before Hurricane Sandy, Leiserowitz et al. (2012) found that two-thirds of Americans connected global warming to recent extreme events, including record high temperatures in the summer of 2012, drought in the Midwest and Great Plains, and record forest fires in the American West. In British Columbia, a Mountain Pine Beetle epidemic caused in part by warmer winters has killed pine forests across millions of hectares, transforming whole landscapes; residents surveyed in nearby communities in 2007 reported that they had been noticing this and other local evidence of climate change for years, listing over 70 conditions that show impacts of climate change (Sheppard, 2012, citing McGuigan, 2007). The survey also suggested a link to behaviour, with about $40 \%$ of participants reporting that "they personally planned to do something in response to climate change" (Sheppard, 2012, p58). Marris (2009, p907) has associated the visible impacts of beetle-kill with policy change: "People see red trees as far as they can see and it becomes easier to implement some rather aggressive policies" on forest management. 
Most people seldom directly experience extreme events associated with climate change; these are still rare episodic events for most communities. They are however starting to see perceived evidence of climate change more often in the media. These periodic vicarious experiences may contribute to general awareness, but they usually do not directly affect the viewers' family and neighbourhood. Emerging evidence suggests that those who directly experience impacts such as flooding (e.g. Spence et al., 2011) express more concern over climate change, see it as less uncertain, recognize more their vulnerability to climate change impacts, and have more confidence in their agency to take action.

In community landscapes of temperate western nations, signs of climate change may be visible but subtle, e.g., gradual changes in plant phenology, species distributions, or water levels. In order to recognize such creeping effects, observation and visual literacy must be improved. While many urban communities have relatively poor observational skills related to natural conditions and trends, some sectors of society are well placed to observe subtle signs and/or track long term trends, due to frequent or repeated activities outdoors: for example, farmers, fishermen, joggers, and dog-walkers (Sheppard, 2014). Could these be the early adopters of a new climate change lens?

There are other precedents for substantive shifts in visual literacy in response to improved knowledge and experience. There is recent quantitative evidence from Californian suburbs that the spread of solar roofs has accelerated in proportion to their visibility to neighbours (Bollinger and Gillingham, 2012). There is also the often cited establishment of social norms for recycling, symbolized by the highly visible blue bins. In this case, the local landscape displays both government support (providing the bins and trucks) and the visible performance of neighbours doing the right thing. It seems therefore that literacy can be built, and that the local landscape can function as a clear signal of important trends, threats, and solutions. Perhaps then, the landscape can serve more systematically as a motivator for behaviour change, changing perceptual frames and social norms.

\section{Learning to recognize climate change holistically in our landscapes}

The public is starting to connect the dots between extreme weather events and climate change, but they may not make the connection to other vital aspects of climate change, such as community vulnerability to other future threats or effective solutions. In field trips with students taking classes on climate change at the University of British Columbia, it is often difficult to find visible examples of actual impacts; it is somewhat easier to identity potential vulnerabilities, such as low spots susceptible to flooding, or hot-spots without shade or cooling features, but even these require knowledge of likely threats and a certain amount of imagination.

Public recognition of carbon as a central cause and driver of climate change is also critical. Can the landscape help us build 'carbon consciousness' (Boardman and Palmer, 2003)? We know that among those who acknowledge that global warming is real, many in America do not believe it is anthropogenic (Maibach et al., 2009). Even those of us who do believe in the human causes of climate change routinely employ cognitive dissonance (Gifford, 2011) to disconnect ourselves from the many local causes of climate change that we could influence. 
In addition, psychological research consistently advocates placing more emphasis on solutions to climate change, rather than dwelling on 'gloom and doom' and generating feelings of guilt or hopelessness (e.g. APA, 2009; CRED, 2009; Gifford, 2011; Moser and Dilling, 2007). This requires more effort in building awareness of mitigation solutions (e.g. improving energy literacy) and of adaptation strategies for local communities.

Consequently, a more holistic lens on climate change in the landscape is crucial. An informed and vigilant public needs the ability to understand the connections between the impacts of climate change, its causes, and both mitigation and adaptation solutions. Invoking the role of landscape can tie local impacts to local (not just global) causes, demonstrate practical solutions, and show what all these things look like on the ground. Using the frame of local landscapes can help people to recognize and make decisions about these vital concepts and community attributes that are currently unfamiliar.

As an aid in this process for community members and non-scientists, a second simple framework is shown in Figure 4a) that combines the local sources of carbon emissions, local climate change impacts and vulnerabilities, ways to reduce carbon emissions (mitigation), and ways to deal with the impacts (adaptation). Figure 4a) integrates these four major components, which we can refer to as Causes, Impacts, Mitigation and Adaptation (CIMA) (Sheppard, 2012). The CIMA framework reflects the structure and key messages of the IPCC reports, is easily remembered by lay-people and students, and addresses the full range of climate change issues that landscape professionals need to grapple with in any location. The diagram also shows multiple interactions among these components: how carbon emissions drive the environmental and other impacts on communities, the effect of mitigation in limiting the causes, the effect of adaptation in limiting the harm from impacts, and the interactions and trade-offs between mitigation and adaptation that are important in multi-facetted planning.

a)

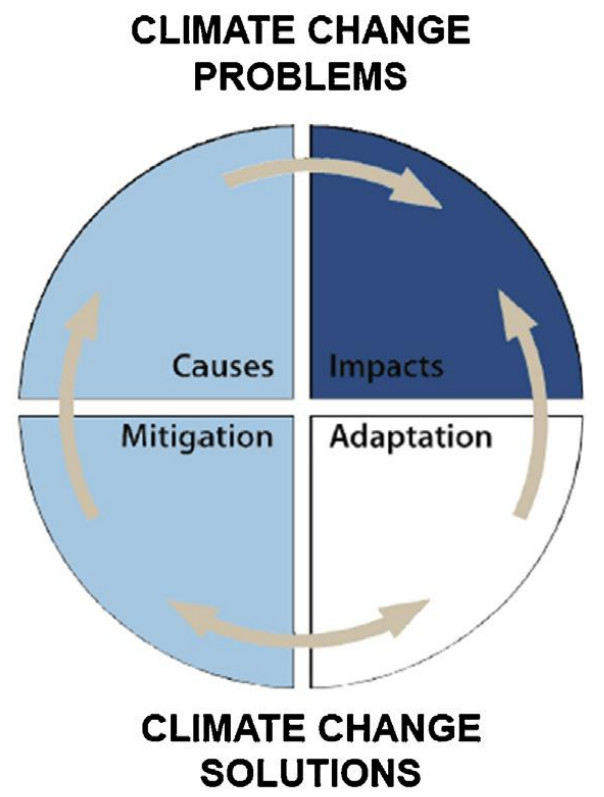

Aspects of climate change focused-on by mass media

\section{b) CLIMATE CHANGE PROBLEMS}

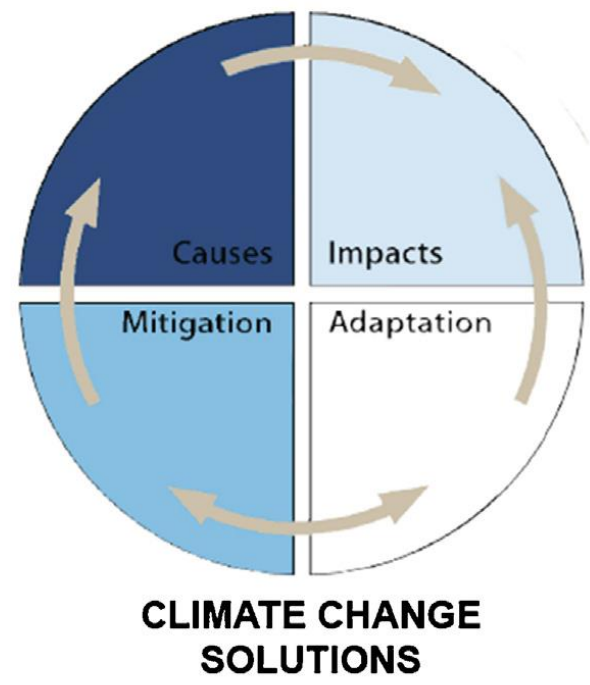

Aspects of climate change most visible in Western communities

Figure 4. The CIMA framework, illustrating relationships between causes, impacts, and solutions to climate change, seen as a whole system. Colour intensity suggests relative prominence of climate change aspects in: (a) 
mass media imagery, emphasizing the dominance of impacts; (b) typical community landscapes (in Western countries), which generally display causes of climate change more vividly than impacts

Graphics: J. Myers \& M. Benedetti. Adapted from 'Visualizing Climate Change’ (Sheppard, 2012).

This simple framework can be used by practitioners or the public to identify and categorize community features that can be associated with the four aspects of climate change, as 'CIMA objects' in existing landscapes. A catalogue of photographs chronicling these features in everyday landscapes can be found in Sheppard (2012), revealing common sources of carbon emissions (e.g. Figure 5a), backyard impacts or vulnerabilities (e.g. Figure 5b), early examples of mitigation (e.g. Figure 5c) and visible adaptation measures (e.g. Figure 5d).
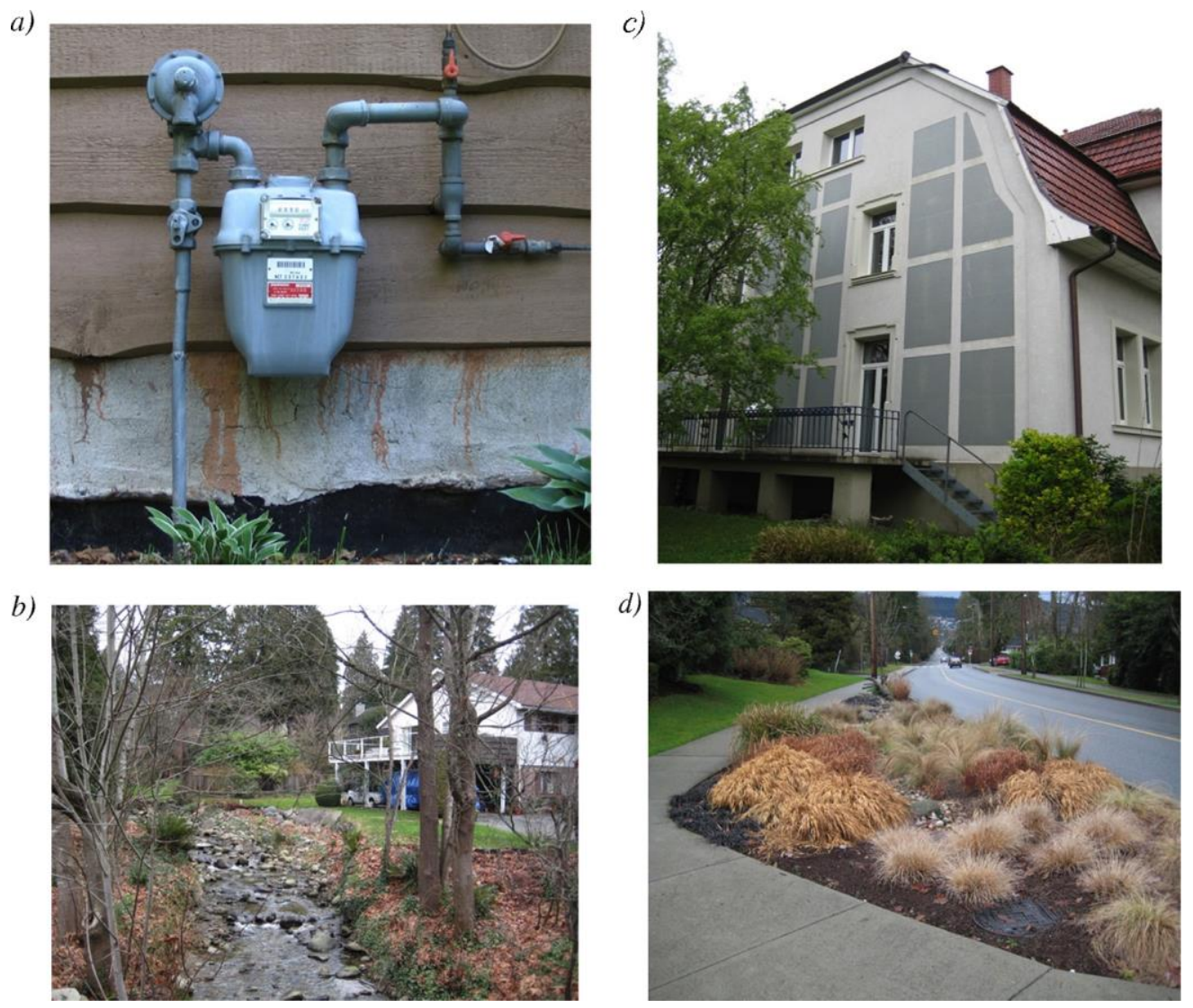

Figure 5. CIMA objects and landscape features: (a) Cause: gas meters show us exactly how much our buildings are causing climate change; (b) Impacts: houses close to fast-running streams demonstrate vulnerability to impacts of intense rainstorms and potential flooding or erosion; (c) Mitigation: external insulation on a heritage home signals reduced carbon emissions through energy conservation; (d) Adaptation: a raingarden shows how we can adapt to more rapid run-off to reduce flooding risks.

Photos: S. Sheppard. Reproduced from 'Visualizing Climate Change' (Sheppard, 2012) with permission from Taylor and Francis.

The CIMA framework can also be used to assess and summarize the relative visibility of climate change components. The media filter on climate change information described above has often focused attention on the 'damage report' from remote climate change impacts or infrequent local extreme weather events, as indicated by the strongest colour intensity in Figure 4a). The media often turn a blind eye to the causes of climate change in residential neighbourhoods, emphasizing industrial smoke stacks rather than the suburban landscapes that typically require commuting by car. Solutions to climate change that are less iconic, such as 
district energy systems running on sewage heat recovery (mitigation) or new farming practices (adaptation), receive little air-time.

The media's selective focus on more dramatic aspects of the climate change system are problematic when they fail to direct public attention to subtle changes and practical positive local solutions. In fact, many aspects of climate change are visible in local communities, but often we just don't know where to look or how to recognize them. As suggested in Figure 4b), the causes of climate change may be the most clearly visible sign of climate change in many communities, where GHG emissions are elevated by vehicle fuel use, heating and cooling of buildings, and embodied energy in infrastructure, food and consumables. Still, these signs are usually ignored and reframed as normal and socially acceptable, while the underlying fossil fuels themselves are usually kept out of sight. Other aspects of climate change are usually much less visible or less easily recognized. Many impacts are gradual and subtle. Some mitigation measures are iconic and easily recognized (e.g. wind turbines or solar panels), but others, "ranging from backyard chicken coops and push-mowers to infill housing and district energy plants" (Sheppard, 2012, p239), are either still rare or not recognized as related to climate change. In landscapes, adaptation as a concept is perhaps the least well understood and the least prominent of the four components; measures such as enlarging drainage culverts to handle more intense rainstorms go largely unrecognized.

Thus, the very things that are most emphasized to the public in media coverage of climate change, i.e. impacts (Figure 4a), are among the hardest to see in everyday temperate urban landscapes (Figure 4b). Meanwhile, the most visible components (such as suburbs, buildings, traffic) are not strongly associated with climate change. Adaptation loses out in both schemas, as least visible currently in both the media and real life. These realizations help explain why public awareness of climate change components is uneven, and can help prioritize efforts to build citizen literacy.

In transitioning towards climate friendly communities, how can people distinguish low-carbon from high-carbon, and vulnerable from resilient landscapes? What are the most effective ways to open people's eyes to climate change, and foster new social norms so that solutions can be scaled up?

The following sections describe some possible answers, enabled by landscape professionals. However, in addressing this challenge, we must recognize that the very aspect of local landscapes that makes them potentially powerful drivers of positive social change - place attachment, aesthetic qualities, keeping up with the Jones's -- can also stymie needed change. There is the issue of resistance to new technologies such as solar panels or wind turbines that conflict with local character (Pasqualetti et al., 2002), and policy conflicts with low-carbon measures, as in prohibition of washing lines on balconies or in front gardens. We need to learn to love low-carbon resilient landscapes (Selman, 2010), and perhaps also to turn against highcarbon or vulnerable landscape features such as leaf-blowers and wind-prone exotic tree species. What we need most are low-carbon, attractive, resilient communities (Sheppard et al, 2008). 


\section{$5 \quad$ Critical roles for landscape professionals}

The challenges just described call for the approaches and skills of landscape professionals. Climate scientists generally are not trained or well equipped to engage communities in climate change. They speak of science and global risks, their goal is primarily to inform. I believe that landscape professionals on the other hand (preferably working with scientists) are better equipped to move society towards action: they intervene physically at various scales in the landscapes where people live, commute, and recreate. They work at the community or site level using local and science-based information; they engage stakeholders in planning and design processes; they talk about opportunities and design solutions which they bring to life with visual tools; they care about aesthetics and are sensitive (usually!) to people's reactions to what things look like. They can therefore play key roles as integrators, facilitators, visualizers, visionaries, and creators, working in collaboration with other experts.

Should the landscape and planning professions seize these key roles? I believe that we have a moral responsibility to use all legitimate approaches within our power to inform, engage and motivate people to act on climate change. This view is consistent with other normative theories advanced for example in Gobster's ecological aesthetic (Gobster, 1999) and Luymes' rhetoric of visualization on sustainability (Luymes, 2001). Many other types of scientific information and visual media are used explicitly to encourage certain behaviours, as in health warnings on smoking or alcohol-use. On climate change in communities, no other professionals can routinely mobilize such powerful communication and design tools for the public good. We do not have to be highly prescriptive on specific design interventions in the landscape or preferred plans in decision-making processes, but should feel confident about encouraging serious consideration of community climate change solutions.

Such a responsible advocacy position however requires a solid ethical base. This essay advances five general guidelines for engaging communities on climate change using visual learning tools responsibly and effectively (described in more depth in Sheppard, 2012):

- make climate change easily seen and understood (clarity)

- link climate change to people, place and context (connectivity)

- keep the process interesting and inclusive (engagement)

- $\quad$ keep the presentations honest, balanced, and verifiable (trust)

- keep the engagement practical and cost-effective (feasibility).

Making climate change visible and meaningful under these guidelines calls for landscape techniques which range from physical design at the neighbourhood level to the use of visual learning tools in community engagement. These may addresses two main functions: making climate change more visible in existing landscapes, and bringing people's possible future landscapes closer to them. The author here suggests four possible pathways for implementation, addressing site design, production of compelling graphics, enhanced planning processes, and public awareness building. The following sections describe each pathway and its purpose, briefly summarize how it works (with examples and precedents), and considers how it may be implemented effectively.

\section{i. Landscape messaging on climate change:}

What if we saw the landscape as eco-label? Landscape messaging refers to onsite "techniques for revealing the signs of a major phenomenon like carbon/climate change, by 
modifying the community landscape" (Sheppard, 2012, p285). It can be considered an extension of eco-revelatory design (Brown et al., 1998) and landscape agency (Meyer, 2008), focusing more deliberately on informing the public through explicit displays and imaginative design to convey important and verifiable messages or learning outcomes, in this case on climate change. This can be done through a variety of means, from explicit interpretative signage and labelling (e.g. of buildings' carbon emissions), to visible volunteer work programmes on climate change solutions, or large-scale landscape redesign of daylighted waterways to reveal changing hydrological or ecological systems (Figure 6).

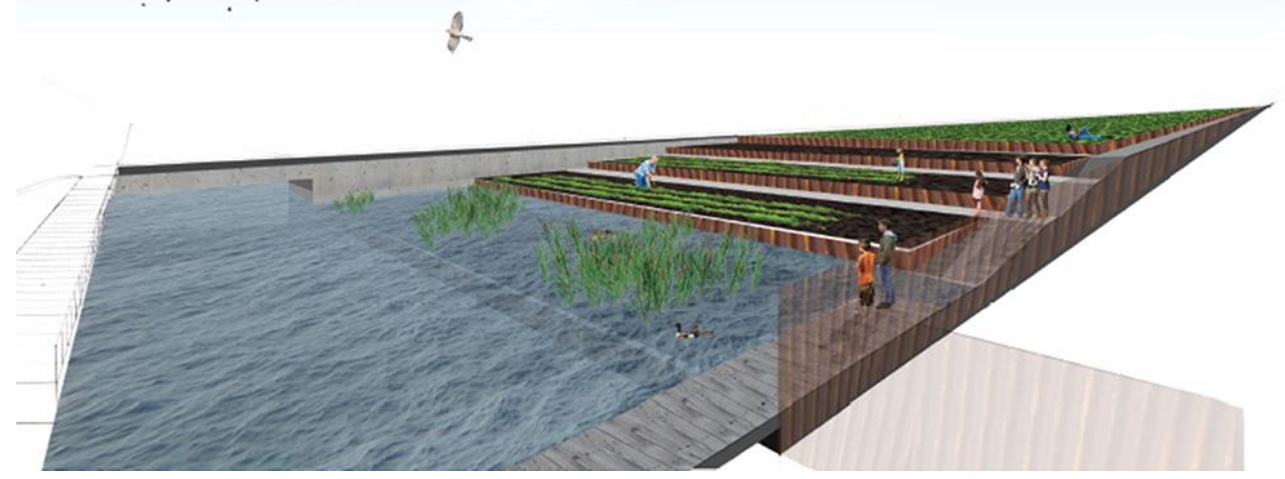

Figure 6. Design concept for an outdoor exhibit using shoreline terraces to demonstrate sea level rise over time. Design/graphic: Michelle Tustin.

The purpose of landscape messaging on climate change would be to increase the visibility of climate change features in local landscapes, and perhaps build broader acceptance of low carbon resilient solutions. Various authors (e.g. Nassauer, 1992, 1994; Brown et al., 1998; Thayer, 1998; Gobster, 1999; Sheppard, 2001) have argued that the visual landscape can and should be manipulated to communicate and foster sustainability, through mechanisms such as culturally recognized cues, transparency of function, and visible stewardship. Examples applied to climate change are still rare; their effectiveness has only been sporadically evaluated and established, such as Baldwin and Chandler (2010) using citizen photographs and events to build public awareness of climate change in Australia. However, interest in landscape messaging appears to be growing, with blue lines being painted on ground or bridges to mark future sea levels in several cities, or the public documentation of a block's collective daily energy usage, charted in chalk on the road surface of Tidy Street in Brighton (Sheppard, 2012), to stimulate social action.

Landscape messaging is then an opportunity not for landscape professionals alone, but also for local governments to go beyond a public art commitment to prioritize landscape messaging in infrastructure projects, in hopes of building public capacity and support for climate-friendly policy and action.

\section{ii. Visualization and other visual learning tools:}

Landscape professionals routinely use a range of graphics to represent local environments, including diagrams, info-graphics, maps, sections, renderings, models and animations (Amoroso, 2015; Ervin \& Hasbrouck, 2001). In particular, we use landscape 
visualization to depict actual places in $3 \mathrm{D}$ perspective views, often with a high degree of experiential realism (Bishop \& Lange, 2005). Visualizations can be usefully applied to the climate change context by: 1) explicitly aligning the visible and the invisible (Nassauer, 2012), through augmented reality or simply combining conceptual and real-world imagery; and 2) "time travel", showing future conditions that make long term consequences more immediate and compelling (Sheppard, 2005). The objectives here are to improve people's understanding of climate change by communicating complex information more clearly, "to convey what it might be like to experience climate change" (Sheppard, 2012, p355) in specific places, and to spark the imagination on possible solutions.

Personal experience in public engagement suggests that many people feel little connection with community planning, and most people have never seen a picture of what climate change could look like in their area. Seeing an image of their community's future can be a transformative moment for local citizens. Documented examples include Swiss ski-hill operators who experienced "Aha" moments when the projected effect of a dwindling snowpack on existing ski runs was visualized (Schroth, 2010); and residents of Kimberley, $\mathrm{BC}$ who experienced emotional reactions to a virtual forest fire threatening their town, simulated in Google Earth (Schroth et al., 2011, 2015).

Because of their dramatic power, it is important that this imagery be scientifically grounded. The goal should be to achieve honest and accurate, defensible visualizations. We might call this 'permissible drama' (Sheppard, 2012): it may include dramatic content such as forest die-back or dike failures (Figure 7) based on empirical evidence or plausible projections, or "dramatic display formats such as big-screen animated panoramas which convey the expected appearance of a future landscape as it would actually be seen in a real place" (Sheppard, 2012, p368). However, the context, uncertainties, and basis of such projections should always be disclosed, and visualizations should not exaggerate the effects of climate change, distort landscape features, or selectively omit key elements. More complete guidance has been put forward in various principles and a code of ethics for landscape visualization (see for example Mulder et al., 2007; Sheppard \& Cizek, 2009). 


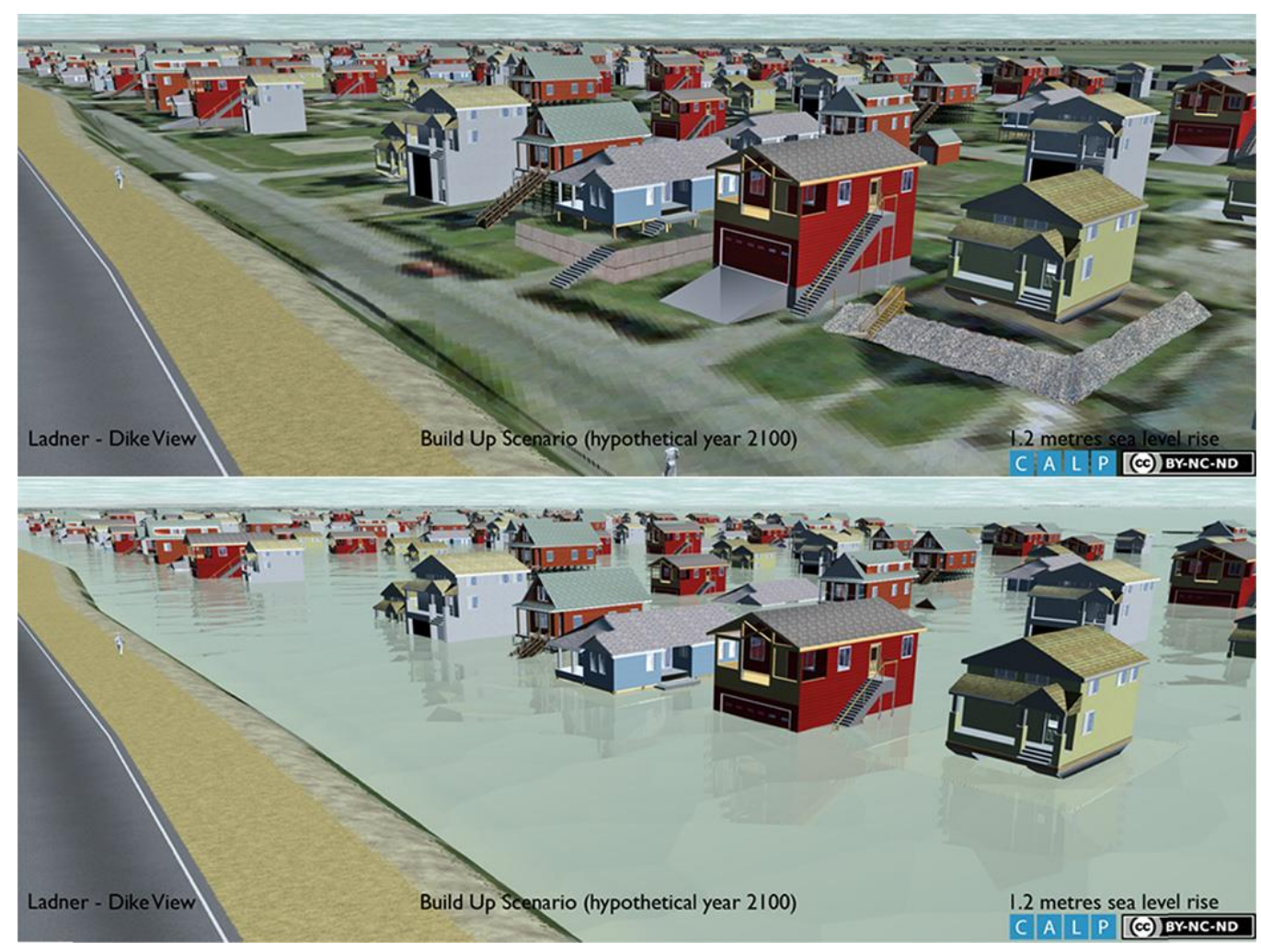

Figure 7. Visualization of a potential flood adaptation strategy to build up homes and key infrastructure in Delta, $\mathrm{BC}$, before and after a dike breach with sea level rise in 2100.

Visualization: D. Flanders, CALP. Source: http://delta-adaptation-bc.org

Without such guidelines, there is considerable risk that contested or discredited visualizations may harm the appropriate use of much-needed visual learning tools, and that useful images will be suppressed for fear of negative outcomes (such as polarizing public debates or plummeting property values for depicted coastal properties). A professionally endorsed code of ethics or standards is thus long overdue, together with supportive training programs for practitioners.

\section{iii. Visioning studies for planning and decision-making}

An important vehicle for making visual learning tools both accessible and defensible is to embed them within structured participatory visioning processes that explore "alternative future landscapes" (Nassauer, 2012), explicitly incorporating climate change conditions. This amounts to better participatory planning, engaging more people, explaining local climate change issues, building community capacity and articulating practical choices. In some jurisdictions, practitioners are increasingly conducting vulnerability studies or community energy plans, but all too often these are carried out as separate studies, losing the opportunities for synergies and efficiencies in joint adaptation and mitigation planning (Bizikova et al., 2008). Communities need a simple but more holistic, flexible framework to integrate the best available knowledge into policy and decision-making, while fostering social learning with citizens and stakeholders as active participants.

Various approaches to visioning have been attempted with embedded visual media and future scenarios, such as integrated modelling and mapping of land use change with climate change in South Oxfordshire (Wood et al., 2006; Perez-Soba et al., 2015); and the City of 
North Vancouver's 100 Year Vision charrette (Condon et al., 2009) with spatial modelling of alternative GHG emission outcomes. The New York Harbour shoreline design exhibition Rising Currents used multiple media to re-envision adaptive infrastructures for sea level rise, fostered considerable public dialogue (Bergdoll, 2011). Kwartler (2005) reports an urban visioning study with residents of Santa Fe, New Mexico, that led to a consensus on doubling densities that was otherwise unlikely to have been supported.

Some evaluation of the effectiveness of visioning has been carried out with an integrated approach termed Local Climate Change Visioning (Pond et al., 2010; Shaw et al. 2009). This process addresses elements included in the CIMA framework described above, through a form of participatory integrated assessment (Salter et al., 2010) to develop future scenarios, with GIS mapping, and systematic use of 3D visualizations. Researchers at the Collaborative for Advanced Landscape Planning (CALP) worked with the coastal community of Delta facing sea-level rise, and the urban fringe of Vancouver's Northshore mountains, affected by reduced snowpack and other hazards. In both communities, visioning packages with maps, diagrams and landscape visualizations were organized around four alternative local landscape scenarios out to 2100 , advised by a multistakeholder working group. The visioning packages illustrated "different levels of climate change impacts, adaptive responses, and mitigation measures in combination........ E.g. North Vancouver's dwindling springtime snowpack (see LUP cover image)..... or resilient low-carbon community retrofits with renewable energy (and) local food production" (Sheppard, 2012, p402).

This approach raised citizens' awareness of climate change, improved support for local mitigation and adaptation policies, and in some cases increased reported motivation to change behaviour (Cohen et al., 2012; Sheppard et al., 2011). In pre-post evaluation workshops with environmental practitioners for example, participants' views on climate change became more urgent when serious local climate change effects were described as "now" rather than 20 years away (Sheppard, 2012). In another planning process in Kimberley, BC, residents recorded a significant increase in concern over local impacts of climate change; and improved understanding of links between climate change and land use decisions. Longitudinal studies have documented several policies and projects implemented as an outcome of Kimberley's adaptation planning process (Schroth et al., 2015).

Guidance on more integrated approaches to climate change planning and communications is now emerging (e.g. Pond et al., 2010; Barry and Weigeldt, 2012). However, this needs to be accompanied by upgrading of professional skills through training and adoption of best practice procedures by local government.

iv. Fostering local learning and community action on climate change

Community members who can recognize climate changes in their surroundings and champion local action should be supported and encouraged. Landscape professionals have the potential to catalyze community-led activities with support and training for residents using do-it-yourself (DIY) visual tools, community mapping, citizen science, and volunteer networks. Direct interaction with place-based communities, (i.e. local climate change tours, mapping and labelling local climate change features, social media activities, etc.) could stimulate learning. New and visually attractive forms of online local data are becoming available for citizens' use in learning about climate change solutions such as community 
energy (e.g. Barron et al., 2013). Using social media, citizens can reveal, record, and share the signs of climate change and neighbourhood actions for mitigation or adaptation.

Precedents for these kinds of grass-roots activities include mapping of urban trees ('Neighbourwoods') by citizens of Sarnia, Ontario (Kenney \& Puric-Mladenovic, n.d.), and the Project Neutral campaign in Toronto to encourage neighbourhoods to transition towards carbon neutrality (Project Neutral, 2014). Few of these projects have been rigorously evaluated, although relevant guidance is emerging: for example, on developing a composite foodshed map for self-sufficiency in local food (Hopkins et al., n.d.), and on exploring sea level rise solutions with visual media (SFU, 2014). Examples of holistic climate change mapping with prototypical neighbourhood toolkits (adapted from basic spatial analysis techniques often used by landscape architects) for use by citizens in learning about their own block, are shown in Figure 8.

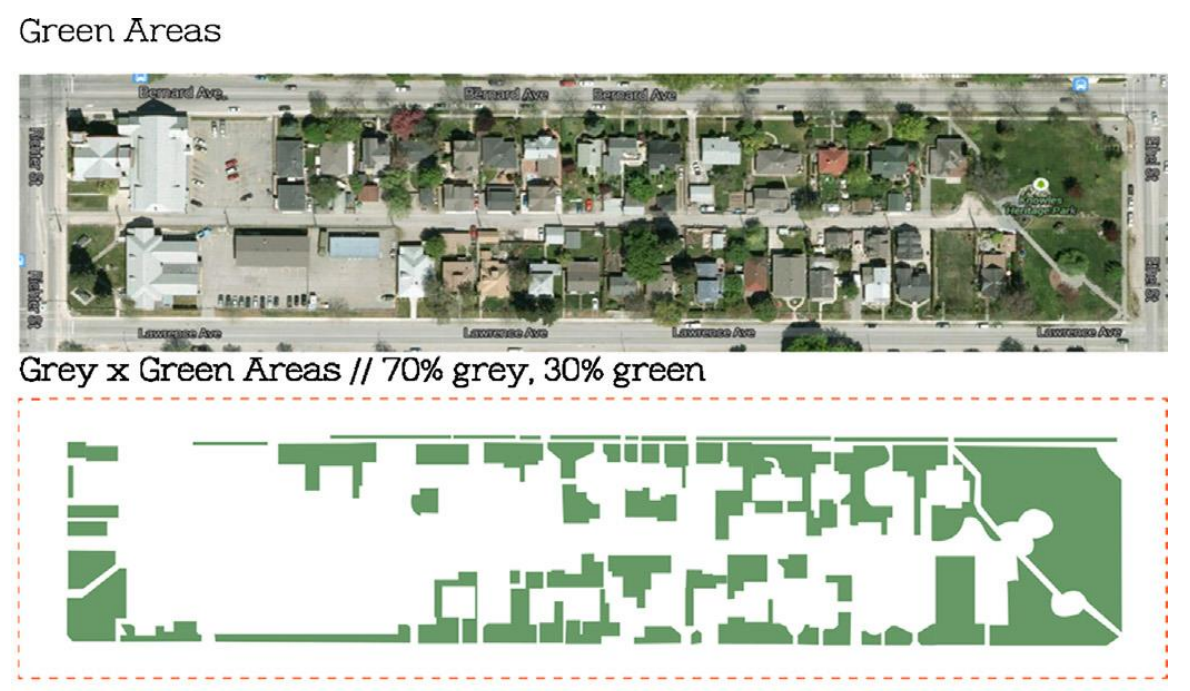

Hot Spots
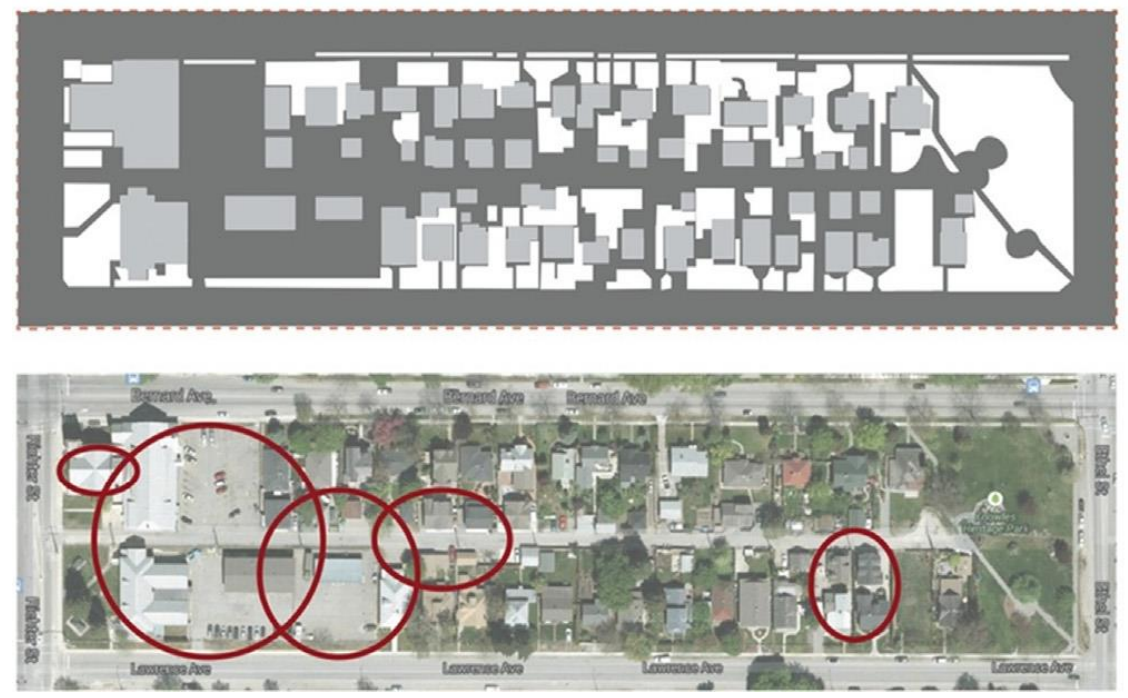

Figure 8. Examples from a block toolkit for citizen mapping of climate change, using grey-green analysis of impervious areas and identification of potential hot-spots in heat waves, as used in a public workshop in Kelowna, $\mathrm{BC}$. 
Graphics: M. Benedetti.

\section{Conclusions}

Given how far we are globally and locally from meeting GHG reduction targets for avoiding catastrophic climate change, there is an urgent need to reveal the signs of climate change in local landscapes and develop strong images of attractive, low-carbon resilient futures. This essay has tried to make the case for broad, local climate change engagement and awarenessbuilding, using the medium of landscape (and its representation in visual media) as a major stimulus. Everyday landscapes offer opportunities for experiential learning on climate change and for the leveraging of place attachment and social pressure, to help mobilize climate change literacy and action on solutions. The essay argues for the development of a new 'climate change lens' through which citizens can see and recognize climate change in their local landscapes, leading perhaps to more caring and more action. This new way of seeing needs to embrace the causes, impacts, mitigation and adaptation of climate change, as a way to make it more connected to everyday life.

If such approaches are to succeed, landscape practitioners (and their professional organizations) can and should play a critical role, expanding beyond more traditional areas of practice such as site design and construction. A range of landscape design and community engagement techniques with compelling visual learning tools will be needed, with governments mainstreaming these into enhanced planning and structured visioning processes. The potential for more work of this type in the landscape field grows every day as the climate changes and communities react. Four ways that landscape professionals can contribute to social change are recommended: design and development of landscape messaging to reveal climate change in current landscapes; production of compelling visualization of climate change in current and future landscapes; leading visioning processes that engage communities in planning for future scenarios with climate change; and helping neighbourhoods to self-educate and mobilize for local deliberation and action.

There is a need for more testing of methods, guidance, and training of professionals in effective use of visualization tools and visioning processes that integrate climate science and landscape planning, and can empower communities to take action. This essay calls for a more systematic use of visual learning tools, and for ethical standards set by professional organizations to produce compelling, credible visualizations. There can hardly be a more important cause or professional opportunity than this, in taking a leadership role on making climate change (and its solutions) visible to the public. 


\section{References}

American Psychological Association (APA). (2009). Psychology and global climate change: addressing a multi-faceted phenomenon and set of challenges, A Report by the American Psychological Association's Task Force on the Interface between Psychology and Global Climate Change. http://www.apa.org/science/about/publications/climate-change-booklet.pdf

Amoroso, N. (ed.). (2015). Representing Landscapes: Digital. London and New York:

Routledge.

Baldwin, C. \& Chandler, L. (2010). At the water's edge: Community voices on climate change, Local Environment, 15(7), 637-649.

Barron, S., Tooke, T.R., Cote, S., Sheppard, S.R.J., Kellett, R., Zhang, K., Holy, L., Sherriff, M., \& vanderLaan, M. (2013). An Illustrated Guide to Community Energy. Vancouver, BC: Collaborative for Advanced Landscape Planning, UBC. http://www.energyexplorer.ca/guide/?p=490

Barry, L. and Weigeldt, N. (2012). Having the Climate Conversation: Strategies for Local Governments. ICLEI - Local Governments for Sustainability (Management) Inc.

Bergdoll, B. (2011). Rising Currents: Projects for New York's Waterfront. Museum of Modern Art, New York. http://www.momastore.org/webapp/wcs/stores/servlet/ProductDisplay?langId=1 \&storeId=10001\&catalogId=10451\&productId $=187628 \&$ promoCode $=8 \mathrm{H} 104 \&$ categoryId $=55$ $161 \&$ parent_category $r n=26683 \& \mathrm{~cm} \_$mmc=MoMA-_Other- _-Exhibitions- _-NA

Bishop, I.D. \& Lange, E. (Eds.). (2005). Visualization in Landscape and Environmental Planning: Technology and Applications, London and New York: Taylor \& Francis Group.

Bishop, I.D., Ye, W.S., \& Karadaglis, C. (2001). Experiential approaches to perception response in virtual worlds, Landscape Urban Planning, 54, 115-123.

Bizikova L., Neale, T., \& Burton, I. (2008). Canadian communities' guidebook for adaptation to climate change. First Edition. Environment Canada and University of British Columbia, Vancouver.

Boardman, B, \& Palmer, J. (2003). Consumer choice and carbon consciousness for electricity, 4CE Final Report, sponsored by the European Commission, available at: http://www.electricitylabels.com/downloads/4CE_Final_Report.pdf

Bollinger, B., \& Gillingham, K. (2012). Peer Effects in the Diffusion of Solar Photovoltaic Panels. Marketing Science September 20, 2012, 900-912.

Boykoff, M.T. (2011). Who Speaks for the Climate? Cambridge University Press.

Brown, B., Harkness, T., \& Johnston, D. (1998). Eco-revelatory design: Nature constructed/nature revealed. Landscape Journal (Special issue), pp.138. 
Carlson, A. (2001). Aesthetic Preferences for Sustainable Landscapes: Seeing and Knowing, in S.R.J. Sheppard \& H.W. Harshaw (Eds.), Forests and Landscapes: Linking Ecology, Sustainability, and Aesthetics, IUFRO Research Series No. 6. . Wallingford, UK: CABI.

Castree, N. (2015). Book review: Visualizing Climate Change: A Guide to Visual Communication of Climate Change and Developing Local Solutions. Progress in Human Geography, 39, 115-118.

Centre for Research on Environmental Decisions (CRED). (2009). The Psychology of Climate Change Communication: A Guide for Scientists, Journalists, Educators, Political Aides, and the Interested Public. New York: Columbia University.

Cohen, S., Sheppard, S.R.J., Shaw, A., Flanders, D., Burch, S., Taylor, W., Hutchinson, D., Cannon, A., Hamilton, S., Burton, B., \& Carmichael, J. (2012). Downscaling and visioning of mountain snow packs and other climate change implications in North Vancouver, British Columbia. Mitigation Adaptation Strategies for Global Change 17(1), 25-49.

Condon, P., Muir-Owen, S., \& Miller, N. (2009). 100 Year Sustainability Vision. Vancouver, Canada: The Design Centre for Sustainability, UBC.

Ervin, S.M., \& Hasbrouck, H.H. (2001). Landscape Modelling. , New York: McGraw Hill.

Gifford, R. (2011). The dragons of inaction: Psychological barriers that limit climate change mitigation and adaptation. American Psychologist, 66 (4), 290-302.

Gobster, P.H. (1999). An ecological aesthetic for forest landscape management. Landscape Journal 18(1), 54-64.

Gobster, P. H., Nassauer, J. I., Daniel, T. C., \& Fry, G. (2007). The shared landscape: What does aesthetics have to do with ecology? Landscape Ecology, 22, 959-972.

Hopkins, R., Thurstain-Goodwin, M., \& Fairlie, S. (Undated). Can Totnes and District Feed Itself? Exploring the practicalities of food relocalisation. Working Paper Version 1.0. Totnes, UK: Transition Network, http://transitionculture.org/wpcontent/uploads/cantotnesfeeditself1.pdf

ICLEI. (Undated). Changing Climate, Changing Communities: Guide and Workbook for Municipal Climate Adaptation. ICLEI, Canada.

http://www.icleicanada.org/images/icleicanada/pdfs/GuideWorkbookInfoAnnexes_WebsiteCom bo.pdf

IPCC. (2014). Summary for policymakers. In: Climate Change 2014: Impacts, Adaptation, and Vulnerability. Part A: Global and Sectoral Aspects. Contribution of Working Group II to the Fifth Assessment Report of the Intergovernmental Panel on Climate Change [Field, C.B., V.R. Barros, D.J. Dokken, K.J. Mach, M.D. Mastrandrea, T.E. Bilir, M. Chatterjee, K.L. Ebi, Y.O. Estrada, R.C. Genova, B. Girma, E.S. Kissel, A.N. Levy, S. MacCracken, P.R. Mastrandrea, and L.L. White (eds.)]. Cambridge, United Kingdom and New York, NY, USA: Cambridge 
University Press, pp. 1-32.

Kahan, D. (2010). Fixing the communications failure. Nature, 463, 296-297.

Kenney, W.A., \& Puric-Mladenovic, D. (Undated). Neighbourwoods: Community-based urban forest stewardship. http://www.forestry.utoronto.ca/neighbourwoods/web/

Kwartler, M. (2005). Visualization in support of public participation. In I. Bishop \& E. Lange (eds.), Visualization in landscape and environmental planning: Technology and Applications. London and New York: Taylor \& Francis Group.

Leiserowitz, A. (2007). Communicating the risks of global warming: American risk perceptions, affective images, and interpretive communities, in S. Moser and L. Dilling (eds.) Creating a Climate for Change: Communicating climate change and facilitating social change. Cambridge, UK: Cambridge University Press.

Leiserowitz, A., Maibach, E. \& Roser-Renouf, C. (2009). Climate change in the American mind. George Mason University, Centre for Climate Change Communication.

Leiserowitz, A., Maibach, E., Roser-Renouf, C., Feinberg, G., \& Howe, P. (2012). Extreme Weather and Climate Change in the American Mind. Yale University and George Mason University. New Haven, CT: Yale Project on Climate Change Communication.

Luymes, D. (2001). The rhetoric of visual simulation in forest design: Some research directions. In S.R.J. Sheppard, and H.W. Harshaw (Eds.), Forests and Landscapes: Linking Ecology, Sustainability, and Aesthetics. IUFRO Research Series, No. 6. Wallingford, UK: CABI Publishing. Pp. 149-172.

Maibach, E., Roser-Renouf, C., and Leiserowitz, A. (2009). Global warming's six Americas 2009: An audience segmentation, available at: http://www.americanprogress.org/issues/2009/05/pdf/6americas.pdf.

Mann, M. E. (2014). If You See Something, Say Something. Opinion, New York Times Sunday Review, Jan. 17, 2014. http://www.nytimes.com/2014/01/19/opinion/sunday/if-you-seesomething-say-something.html

Marris, E. (2009) Planting the forest of the future, Nature, 459, 906-908

Marshall, G. (2014). Don't Even Think About it: Why Our Brains Are Wired to Ignore Climate Change. New York: Bloomsbury USA.

McGuigan, E. (2007). Climate change perception study: Qualitative results. Report prepared for CANFOR. Collaborative for Advanced Landscape Planning, University of British Columbia, Vancouver, BC.

McKenzie-Mohr, D. and Smith, W. (1999). Fostering sustainable behavior: An introduction to community-based social marketing, Gabriola Island, B.C., Canada: New Society Publishers. McKibben, W. (2012). Foreword in S.R.J. Sheppard, Visualizing Climate Change, p.vi, Abingdon, UK: Earthscan/Routledge. 
Metz, D., \& Below, C. (2009). Local Land Use Planning and Climate Change Policy, Working Paper prepared for Lincoln Institute of Land Policy, available at:

http://www.lincolninst.edu/pubs/1729_Local-Land-Use-Planning-and-Climate-Change-Policy

Meyer, E.K. (2008). Sustaining beauty: The performance of appearance - a manifesto in three parts. Journal of Landscape Architecture, Spring 2008, pp 6-23.

Moser, S., \& Dilling. L. (Eds). (2007). Creating a Climate for Change: Communicating climate change and facilitating social change. Cambridge, UK: Cambridge University Press.

Mulder, J., Sack-da-Silva, S., \& Bruns, D. (2007). Understanding the role of 3D visualizations: The example of Calden Airport expansion, Kassel, Germany, in A. van den Brink, R. van Lammeren, R. van de Velde, and S. Dane (Eds.), Geo-visualization for Participatory Spatial Planning in Europe: Imagining the Future. Wageningen, NL: Manschold Publication Series, vol3, Wageningen Academic Publishers.

Nassauer, J.I. (2012). Landscape as medium and method for synthesis in urban ecological design. Landscape and Urban Planning 106, 221-229.

Nassauer, J.I. (1992). The appearance of ecological systems as a matter of policy. Landscape Ecology 6(4): 239-250.

Nassauer, J. I. (1994). 'Messy ecosystems, orderly frames', Landscape Journal, 14, 161-171.

Nordhaus, T., \& M. Shellenberger. (2009). Apocalypse Fatigue: Losing the Public on Climate Change. Environment 360, Yale School of Forestry and Environmental Studies. Posted 16 November 2009, http://e360.yale.edu/feature/apocalypse_fatigue_losing_the_public_on_climate_change/2210/

O’Shea, M. (2014). Greenest City Conversations: Final Project Report. Victoria, BC: Pacific Institute for Climate Solutions. http://pics.uvic.ca/sites/default/files/uploads/GCC\%20project\%20report\%202014.pdf

Pahl, S., Sheppard, S.R.J., Boomsma, C., \& Groves, C. (2014). Perceptions of time in relation to climate change. Wires Climate Change, February 2014. DOI: 10.1002/wcc.272

Pasqualetti, M.J., Gipe, P., \& Righter R.W. (2002). Wind Power in View: Energy Landscapes in a Crowded World. Academic Press.

Perez-Soba, M., Paterson, J., \& Metzinger, M. (2015). Vision of future land use in Europe: stakeholder visions for 2040. VOLANTE Project Report, Alterra Wageningen UR, 24pp. ISBN 978-94-6257-406-9.

Pond, E., Schroth, O., Sheppard, S.R.J., Muir-Owen, S., Liepa, I., Campbell, C., Flanders, D., \& Tatebe, K. (2010). Local climate change visioning and landscape visualizations: Guidance manual. Version 1.0. Prepared for the BC Ministry of Community and Rural Development. Vancouver, Canada: CALP, UBC. 
Project Neutral. (2014). http://www.projectneutral.org/make-your-neighbourhood-carbon$\underline{\text { neutral }}$

Rhodes, E., J. Axsen, \& M. Jaccard. (2014). Does effective climate policy require wellinformed citizen support? Global Environmental Change, Volume 29, November 2014, Pages 92-104

Salter, J., Robinson, J., \& Wiek, A. (2010). Participatory methods of integrated assessment - A review, Wiley Interdisciplinary Reviews, 1(5), 697-717.

Scannell, L. \& Gifford, R. (2010). Defining place attachment: a tripartite organizing framework. Journal of Environmental Psychology 30, 1-10.

http://dx.doi.org/10.1016/j.jenvp.2009.09.006

Schroth, O. (2010). From information to participation: Interactive landscape visualization as a tool for collaborative planning, $\mathrm{PhD}$ thesis, Swiss Federal institute of Technology, ETH, Zurich, Switzerland.

Schroth, O., Pond, E., Campbell, C., Cizek, P., Bohus, S., \& Sheppard, S.R.J. (2011). Tool or Toy? Virtual globes in Landscape Planning. Future Internet 3, 204-227.

www.mdpi.com/journal/futureinternet

Schroth, O., Pond, E., \& Sheppard, S.R.J. (2015). Evaluating presentation formats of local climate change in community planning with regard to process and outcomes. Landscape and Urban Planning, Special Issue on Critical Visualization, http://www.sciencedirect.com/science/journal/aip/01692046

Selman, P. (2010). Learning to Love the Landscapes of Carbon-Neutrality. Landscape Research, 35(2), 157-171.

Shaw, A., Sheppard, S.R.J, Burch, S., Flanders, D., Wiek, A., Carmichael, J., Robinson, J., \& Cohen, S. (2009). How futures matter - synthesizing, downscaling, and visualizing climate change scenarios for participatory capacity building. Global Environmental Change. 19 (2009), 447-463.

Sheppard, S.R.J. (2001). Beyond visual resource management: Emerging theories of an ecological aesthetic and visible stewardship. Chapter 11 in Forests and Landscapes: Linking Ecology, Sustainability, and Aesthetics, S.R.J. Sheppard, and H.W. Harshaw (Eds.). IUFRO Research Series, No. 6. Wallingford, UK: CABI Publishing. Pp. 149-172.

Sheppard, S. R. J. (2005). Landscape visualization and climate change: The potential for influencing perceptions and behaviour. Environmental Science and Policy, 8, 637-654. Sheppard, S.R.J. (2012). Visualizing Climate Change: A Guide to Visual Communication of Climate Change and Developing Local Solutions. Abingdon, UK: Earthscan/Routledge. http://visualizingclimatechange.ca

Sheppard, S.R.J. (2014). Dog walker blog post, http://visualizingclimatechange.ca/blog/ 
Sheppard, S.R.J., \& Cizek, P. (2009). The Ethics of Google-Earth: Crossing thresholds from spatial data to landscape visualization. J. Environmental Management. 90, 2102-2117.

Sheppard, S., Pond, E. \& Campbell, C. (2008). Low-carbon, attractive, resilient communities: New imperatives for sustainable retrofitting of existing neighbourhoods. Paper presented at Council for European Urbanism Third International Congress, Oslo, Norway.

Sheppard, S.R.J., Shaw, A., Flanders, D., Burch, S., Wiek, A., Carmichael, J., Robinson J., \& Cohen, S. (2011). Future visioning of local climate change: A framework for community engagement and planning with scenarios and visualisation. Futures 43(4), 400-412.

Simon Fraser University (SFU). (2014). RISE: An Ideas competition addressing Sea Level rise - 5 tools to enhance your presentation. October 1, 2014. SFU Public Square, Vancouver, BC. http://www.sfu.ca/rise/news/blog/5-tools-enhance-presentation.html

Snover, A.K., Whitely Binder, L., Lopez, J., Willmott, E., Kay, J., Howell, D., \& Simmonds, J. (2007). Preparing for Climate Change: A Guidebook for Local, Regional, and State Governments. Oakland, CA: ICLEI - Local Governments for Sustainability.

Spence, A., Poortinga, W., Butler, C., \& Pidgeon, N.F. (2011). Perceptions of climate change and willingness to save energy related to flood experience. Nature Climate Change 1, 46-49.

Thayer, R. (1998). Landscape as an ecologically revealing language. Landscape Journal Special Issue on Eco-revelatory Design, 1998, pp. 118-129.

Van Der Linden, S. (2014). Towards a new model for communicating climate change. In S. Cohen, J. Higham, P. Peeters and S. Gössling (Eds.). Understanding and governing sustainable tourism mobility: Psychological and behavioural approaches (pp. 243-275). Routledge: Taylor and Francis Group.

Weber, E. U. (2006). Experience-based and description-based perceptions of long-term risk: Why global warming does not scare us (yet). Climatic Change, 77, 103-120.

Winn, W. (1997). The impact of three-dimensional immersive virtual environments on modern pedagogy. Human Interface Technology Laboratory Technical Report R-97-15, University of Washington, Seattle, WA.

Wood, P., Berry, P.M. \& Lonsdale, K. (2006). Future Landscape Scenarios around Little Wittenham, South Oxfordshire. Report to the Northmoor Trust. 